\title{
PEMERIKSAAN KLINIK BERBASIS BIOSENSOR BAGIAN 2: Biosensor Virus Untuk Deteksi Penyakit Patogen
}

\author{
Nur Habibah ${ }^{1}$
}

\begin{abstract}
Nowadays, rapid determination of several viruses which caused pathogen diseases is really important. Most of rapid detection of human pathogen viruses was developed by using biosensor technology. Biosensor technology offers several advantages, such as simple, efficient, low cost, fast response, easy to operate, and reliable. Viral detection by using biosensor can also avoid the delay of diagnosis, so the doctor can determine the type of drugs quickly and also can decide the type of patient care, properly.

Most of biosensor for virus detection was exploited by using electrochemical principle, with amperometric and volumetric transducer. Almost of virus biosensor used immobilized antibody onto electrode surface as a biorecognition element. Some of viruses that could be detected by using electrochemical biosensor are HCV, HBV, HIV and influenza virus.

However, quality control of the biosensor result is important, so the biosensor could be selected as an alternative method for on-site determination, especially in clinical determination.
\end{abstract}

Keywords: biosensor, virus biosensor, virus detection, pathogen diseases detection

\section{PENDAHULUAN}

Dewasa ini, kebutuhan terhadap metode analisis yang cepat, akurat, efektif, efisien dan mudah serta murah terus meningkat. Hal ini tentu saja menjadi tantangan baru bagi peneliti, tidak terkecuali di bidang pengembangan pemeriksaan klinik. Metode baru yang mulai banyak dikembangkan saat ini adalah teknologi sensor dan biosensor. Biosensor dikembangkan dengan mengintegrasikan sinyal biologis dari molekul seperti enzim, antibodi, fag-aptamer, atau rantai tunggal
DNA dengan suatu transduser fisikokimia yang sesuai, menjadi sinyal elektrik yang bermakna $^{1,2}$. Sejak pertama kali dikembangkan oleh Clark dan Lyons pada tahun 1962 dengan mengimobilisasi enzim glukosa oksidase pada permukaan elektroda untuk mendeteksi glukosa darah, teknologi biosensor berkembang sangat pesat, salah satunya biosensor untuk mendeteksi virus ${ }^{3}$.

\footnotetext{
1.,2.,3., Jurusan Analis Kesehatan Poltekkes Denpasar Korespondensi : Nur Habibah ${ }^{1}$, Jurusan Analis Kesehatan, Poltekes Denpasar, Jalan Sanitasi No. 1 Sidakarya, Denpasar-Bali 80224, Indonesia.

Telp. +62-361-710 527, Fax. +62-361-710 448

Email : meditoryjournal@gmail.com
} 
Setiap jenis virus memiliki mekanisme aksi yang berbeda. Secara umum virus terdiri dari virion $(10-100 \mathrm{~nm})$, yang mengandung genom DNA atau RNA yang dikemas dalam suatu kapsid ${ }^{4}$. Asam nukleat virus berfungsi untuk membawa informasi genetik yang diperlukan saat replikasi virus pada sel inang, sedangkan kapsid berfungsi untuk melindungi asam nukleat dari nukleasis dan membantu proses penempelan virus ke sel inang. Virus memerlukan sel inang untuk dapat bereproduksi dan bertahan hidup, dan sebagian besar virus bersifat patogen bagi manusia ${ }^{3,4,5}$. Virus dapat berpindah melalui makanan dan lingkungan, misalnya HRV, HEV, HAVs, astrovirus, sapovirus, enterovirus, coronavirus, parvovirus, rotavirus, adenovirus, dan lain-lain ${ }^{4}$. Hingga saat ini, rotavirus masih menjadi salah satu penyebab utama diare pada anak, dan dilaporkan menyebakan kematian hingga 5\% penderita setiap tahunnya. Adenovirus merupakan virus yang menyebabkan infeksi saluran nafas, okular hingga enterik. Virus tersebut merupakan satu dari banyak virus yang sulit didiagnosa, karena memberikan gejala yang sangat sedikit ${ }^{5}$. Di beberapa negara berkembang, penyakit yang disebabkan oleh virus lain seperti malaria, TB, pneumonia, influenza dan HIV pernah menjadi pandemi ${ }^{3}$ Penyakit yang disebabkan oleh virus dapat dicegah, tetapi sayangnya ratusan bahkan ribuan kasus kematian, terutama yang menimpa anak-anak dan balita setiap tahunnya disebabkan oleh virus ${ }^{5}$. Oleh karena itu, penyakit patogen yang disebabkan oleh virus menjadi masalah serius yang perlu diperhatikan.

Hingga saat ini, proses deteksi dan kuantifikasi virus masih banyak dilakukan dengan metode konvensional. Metode konvensional yang banyak dilakukan adalah pengujian secara mikrobiologi. Meskipun metode pengujian tersebut memiliki sensitivitas yang cukup tinggi, namun pengujian secara mikrobiologi memerlukan waktu yang relatif lama, meliputi tahap kultur sel yang membutuhkan waktu 2-10 hari, tergantung pada jenis virus yang dideteksi, diikuti dengan tahap pengujian imunologi. Selain itu, pengujian secara mikrobiologi harus dilakukan oleh tenaga ahli $^{3,4}$.

Infeksi yang disebabkan oleh virus seringkali memberikan gejala umum yang hampir sama, sehingga menyulitkan dokter untuk menentukan diagnosa. Penggunaan teknologi biosensor untuk mendeteksi virus akan memungkinkan dokter untuk memastikan virus penyebab suatu infeksi dengan cepat dan memberikan resep dan jenis penanganan yang tepat. Adanya antibodi spesifik dapat dideteksi menggunakan komponen virus sebagai agen 
sensing untuk menunjukkan sejarah infeksi pada pasien non-imunocompromised ${ }^{3}$.

Deteksi dan kuantifikasi virus merupakan hal yang mendasar untuk beragam aplikasi, mulai dari sanitasi dan produksi makanan hingga untuk kepentingan diagnostik dan terapeutik. Pengembangan teknologi biosensor untuk dapat menghasikan biosensor virus yang efisien, sensitif, mudah dan ekonomis masih terus dilakukan hingga saat ini. Terdapat beberapa jenis biosensor virus yang telah dikembangkan, antara lain metode optik seperti Surface Plasmon Resonance (SPR), serat optik, kuantum dot, elektrokimia seperti amperometri, voltametri, impedansi dan material nano ${ }^{6,7,8,9}$ dengan suatu transduser fisikokimia. ${ }^{10}$ Biosensor terdiri dari dua komponen utama, yaitu bioreseptor yang akan mengenali analit target dan transduser yang akan merubah sinyal biologis menjadi sinyal elektrik yang terukur. Pada umumnya, perangkat biosensor juga ditambah dengan amplifier yang berfungsi untuk memperbesar sinyal elektrik yang diterima sehingga dapat dilanjutkan ke bagian pemroses data dengan mudah. Bioreseptor yang digunakan pada umumnya berupa asam nukleat, baik DNA, RNA atau PNA, enzim, antibodi, sel atau mikroorganisme, sedangkan jenis transduser yang digunakan antara lain transduser elektrokimia, optik, pizoelektrik dan termal ${ }^{11}$. Komponen utama biosensor dapat dilihat pada Gambar $1^{4}$.

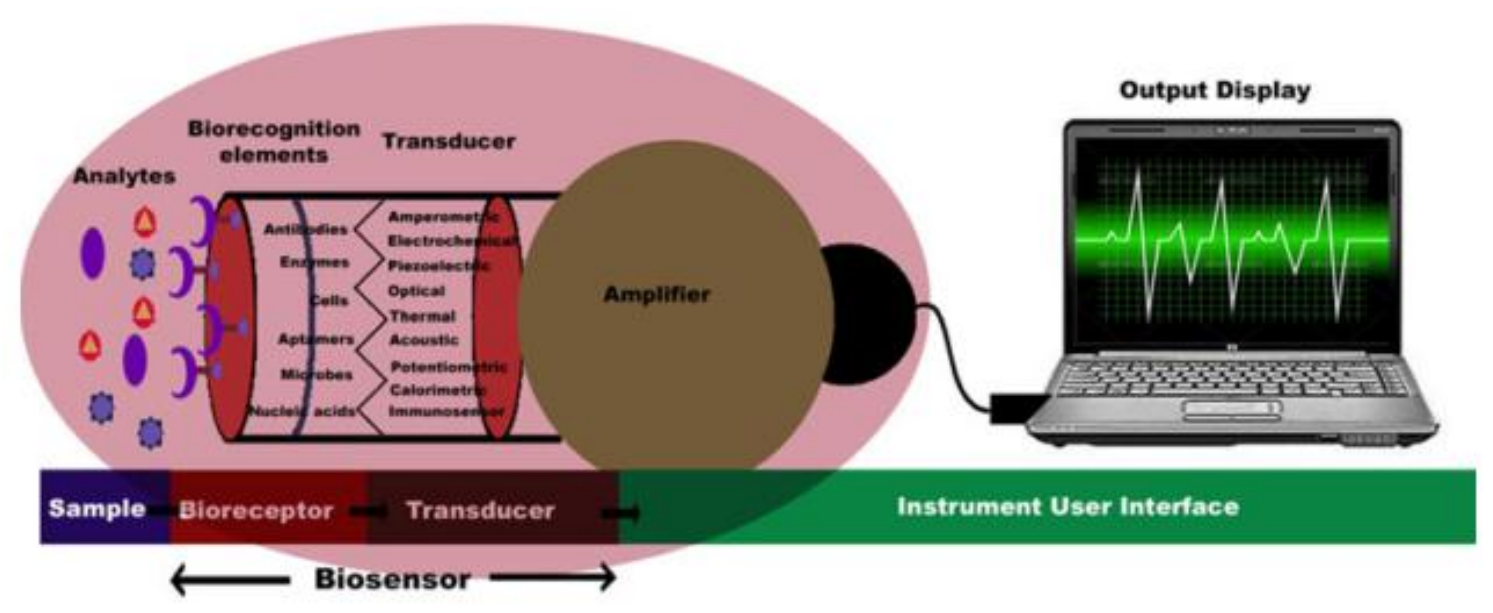

Gambar 1. Komponen utama biosensor

\section{PEMBAHASAN}

\section{Biosensor Virus Elektrokimia: Biosensor}

\section{Amperometri dan Volumetri}

Biosensor adalah perangkat bioanalitik yang mengintegrasikan rekognisi molekul
Sebagian besar biosensor yang digunakan untuk mendeteksi patogen adalah biosensor elektrokimia. Biosensor elektrokimia memiliki beberapa kelebihan dibandingkan dengan transduser lain, antara 
lain memiliki sensitivitas yang tinggi, cocok untuk dikembangkan dalam skala mikro, instrumentasi yang digunakan sederhana, pengukuran tidak dipengaruhi oleh kekeruhan sampel, absorbsi atau fluoresensi komponen dalam sampel, serta dapat digunakan untuk deteksi sampel dengan berbagai jenis pelarut, sifat elektrolit dan temperatur ${ }^{3,11}$. Deteksi secara elektrokimia biasanya digunakan untuk deteksi virus patogen dengan menggunakan rekognisi DNA-DNA, DNA-PNA, DNARNA dan DNA-aptamer asam nukleat. ${ }^{11,12,13,14}$.

Kelebihan lain biosensor elektrokimia adalah dapat digunakan untuk analisis in-situ serta dapat dioperasikan tanpa tenaga ahli. Analisis dan deteksi virus pada biosensor jenis ini didasarkan pada prinsip afinitas, dimana antibodi digunakan untuk "mengikat" virus ${ }^{5}$ Kuantifikasi dengan menggunakan biosensor elektrokimia didasarkan pada pengukuran perubahan arus, potensial dan impedansi, yang diinduksi oleh reaksi biokimia yang terjadi antara bioreseptor dengan target analit. Sebagian besar biosensor elektrokimia menggunakan transduser amperometri danvolumetri ${ }^{11}$.

Pada umumnya, biosensor virus elektrokimia dibagi menjadi 3, yaitu biosensor voltametri, amperometri dan impedansi. Pada biosensor amperometri, hubungan antara arus dengan potensial di ukur di dalam sel elektrokimia, sedangkan biosensor voltametri mengukur tegangan pada saat tidak arus yang dialirkan. Transduser amperometri akan mendeteksi ikatan antara analit dengan bioreseptor jika ada produk yang dapat menyebabkan terjadinya reaksi redoks pada permukaan elektroda, biasanya dilakukan dengan penambahan kompleks enzim antibodiredoks ${ }^{3}$. Pada umumnya biosensor amperometri menggunakan elektroda karbon screen-printed karena lebih stabil, murah, disposable dan dapat digunakan untuk volume dalam jumlah kecil ${ }^{15}$. Permasalahan yang sering ditemukan pada biosensor elektrokimia adalah proses imobilisasi bioreseptor. Pada proses imobilisasi, bioreseptor arus dijaga agar tidak mengalami perubahan dan denaturasi. Selain itu, sensor amperometri dan volumetri sensitif terhadap perubahan $\mathrm{pH}$ dan ikatan molekul yang tidak spesifik sehingga dapat memberikan hasil positif palsu ${ }^{3}$.

Beberapa pengembangan dan aplikasi biosensor elektrokimia untuk proses deteksi virus telah dipublikasikan. Biosensor elektrokimia yang dikembangkan oleh Ding, et al. mampu mendeteksi sekuen virus hepatitis B (HBV) melalui interaksi antara DNA virus dengan indikator redoks 2,9dimetil-1,10-fenantrolin-kobalt. Deteksi 
elektrokimia pada biosensor ini dilakukan menggunakan voltametri siklik dan voltametri diferensial pulsa. Pada kondisi optimum, sinyal elektrik yang dihasilkan memiliki linieritas pada range konsentrasi DNA target sebesar $3,96 \times 10^{-7} \sim 1,32 \times 10^{-6} \mathrm{M}$, dengan limit deteksi $1,94 \times 10^{-8}$ M. hal ini membuktikan bahwa biosensor ini memiliki sensitivitas yang cukup baik. ${ }^{16}$

Biosensor lain yang dikembangkan oleh Arikyosal et al. mampu mendeteksi sekuen DNA virus HBV, menggunakan prinsip deteksi voltametri, dengan memonitor sinyal oksidasi guanin pada pengembangan resistensi lamivudin. Pada kondisi optimum, biosensor ini mampu mendeteksi hingga konsentrasi $457 \mathrm{fmol} / \mathrm{mL}$ DNA target ${ }^{17}$. Biosensor virus HBV yang lain dikembangkan dengan menggunakan indikator hibridisasi bis-(benzimidazol)cadmium(II) dinitrat untuk mengembangkan biosensor elektrokimia sekuen DNA virus HBV. Biosensor ini memiliki range konsentrasi $1,49 \times 10^{-7} \sim 1,06 \times 10^{-6} \mathrm{M}$ dengan limit deteksi $8,4 \times 10^{-8} \quad$ M. $^{18}$ Biosensor HBV lain dikembangkan oleh Zhang et al., dengan menggunakan kompleks diaquabis-[N-(2piridinilmetil)-benzamida- $\left.{ }^{2} \mathrm{~N}, \mathrm{O}\right]-$ cadmium(II) dinitrat sebagai indikator elektroaktif untuk mendeteksi adanya HBV secara voltametri. Biosensor ini dapat mendeteksi DNA virus HBV secara selektif pada range konsentrasi $1,01 \times 10^{-8} \sim 1,62 \times 10^{-6} \mathrm{molL}^{-1}$, dan memiliki

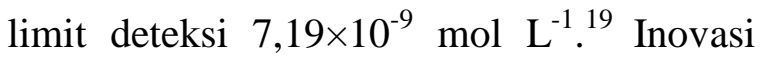
biosensor amperometri lain dikembangkan oleh Lonescu, et al. untuk mendeteksi antibodi Virus West Nile (WNV) dengan mengimobilisasi bakteriofage T7. Biosensor ini terbukti potensial untuk dikembangkan sebagai biosensor untuk diagnosis virus ${ }^{20}$.

Biosensor amperometri lain yang banyak dikembangkan adalah biosensor virus hepatitis $\mathrm{C}(\mathrm{HCV})$. Hepatitis $\mathrm{C}$ adalah penyakit yang ditemukan di hati akibat adanya infeksi virus HCV. Pada umumnya infeksi ini tidak memberikan gejala, namun dapat menyebabkan infeksi kronis yang mengakibatkan terjadinya sirosis hati setelah bertahun-tahun. Pada beberapa kasus, sirosis hati dapat menyebabkan terjadinya gagal fungsi hati, kanker hati, varises lambung dan esofagus yang dapat membahayakan jiwa ${ }^{21}$. Beberapa biosensor $\mathrm{HCV}$ yang pernah dilaporkan antara lain adalah biosensor elektrokimia yang dikembangkan oleh Riccardi et al. Biosensor ini memiliki kelemahan karena memerlukan waktu respon yang relatif lama, yaitu 10 menit $^{22}$. Biosensor elektrokimia untuk deteksi HCV secara kualitatif dan kuantitatif didasarkan pada pembelahan spesifik enzim BamHI endonuklease juga berhasil dikembangkan oleh Liu, et al. Kuantifikasi didasarkan pada perbedaan puncak arus yang bervariasi, 
yang linier pada range konsentrasi $0,1 \sim 2,5 \mu \mathrm{M}^{23}$.

Virus lain yang penting dan dapat menginfeksi manusia adalah virus HIV. HIV adalah lentivirus yang dapat menyebabkan acquired immunodeficiency syndrome, yaitu suatu kondisi dimana terjadi kegagalan progresif dari sistem kekebalan tubuh sehingga dapat menyebabkan infeksi oportunistik yang membahayakan jiwa hingga metastasis sel kanker. Deteksi awal virus HIV sangat penting dilakukan untuk penanganan penyakit serta pencegahan penyebaran penyakit ${ }^{21}$.

Sebagian biosensor elektrokimia untuk deteksi virus HIV dikembangkan menggunakan teknologi nanomaterial. Salah satu biosensor virus HIV yang dikembangkan dengan teknologi nano adalah ultra trace biosensor voltametri, dengan menggunakan matriks nanotubes karbon yang berisi nano partikel perak, yang dilekatkan pada mikroelektroda emas sebagai media pendukung untuk imobilisasi 21-mer ss-DNA. Biosensor ini memiliki bekerja pada range konsentrasi 1 100 pM dengan limit deteksi $0,5 \quad \mathrm{pM}^{24}$. Pengembangan biosensor elektrokimia lain untuk mendeteksi virus HIV-1 dilakukan dengan mengimobilisasi bioreseptor pada matriks nano biokomposit kitosan $/ \mathrm{Fe}_{3} \mathrm{O}_{4}$ dengan menggunakan metilen biru sebagai indikator hibridisasi redoks. Imobilisasi bioreseptor pada matriks pendukung dilakukan berdasarkan pada ikatan kovalen yang terjadi antara sisi aktif elektroda dengan bioreseptor yang digunakan. Penggunaan $\mathrm{Fe}_{3} \mathrm{O}_{4}$ dapat meningkatkan transfer elektron, sehingga mampu meningkatkan sensitivitas sensor. Elektroda pada biosensor ini dilaporkan memiliki limit deteksi yang cukup rendah, yaitu 50 pM dengan stabilitas dan reprodusibilitas yang cukup baik $^{25}$.

Biosensor elektrokimia untuk deteksi jenis virus lain yang juga banyak dikembangkan antara lain adalah biosensor virus influenza $A$, virus avian influenza dan virus papilloma. Salah satu biosensor elektrokimia yang ultrasensitif untuk mendeteksi virus influenza A dikembangkan menggunakan glukosa oksidase yang dideposisikan pada nano partikel perakheksasianoferat. Biosensor ini disebut sebagai biosensor ultrasensitif karena mampu mendeteksi ss-DNA target hingga pada rang konsentrasi femtomolar. Konsentrasi DNA target dikorelasikan dengan puncak arus voltamogram pada voltametri diferensial pulsa. Konsentrasi DNA dapat terkuantifikasi dengan baik jika berada pada range 1,0 10,0 fM, dengan limit deteksi $1,0 \quad \mathrm{fM}^{25}$. Biosensor elektrokimia virus papilloma dikembangkan dengan mengimobilisasi rantai tunggal oligonukleotida (HS-ssDNA) secara 
koadsorpsi spontan pada permukaan elektroda emas screen-printed. DNA yang telah terimobilisasi pada permukaan elektroda tersebut, mampu meng-hibridisasi secara selektif DNA dalam larutan membentuk DNA rantai ganda (ds DNA) pada permukaan elektroda. DNA diperlakukan dalam asam, dan basa purin yang dilepaskan dalam kondisi asam diukur langsng secara voltametri. Pada kondisi optimum, biosensor ini mampu mendeteksi sekuen DNA target hingga pada konsentrasi $2 \mathrm{pgmL}^{-1}$. Biosensor ini meiliki kekurangan, karena hanya dapat digunakan satu kali ${ }^{27}$.

Biosensor Virus Elektrokimia: Biosensor

\section{Impedansi}

Selain hubungan antara arus-potensial dan tegangan, perubahan kapasitansi dan impedansi pada saat terjadi fenomena hibridisasi dapat digunakan untuk kuantifikasi biosensor. Biosensor impedansi elektrokimia untuk deteksi virus pada umumnya dikembangkan menggunakan lapisan monolayer dan polimer konduktif pada permukaan elektroda ${ }^{3}$. Skema biosensor impedansi yang dikembangkan dengan mengimobilisasi antigen pada lapisan monolayer dapat dilihat pada Gambar $2^{3}$.

Proses hibridisasi antara biosensor dengan antivirus yang terimobilisasi, akan menimbulkan respon konduktivitas yang dapat terukur, yang kemudian akan di konversikan menjadi perubahan resisitensi dan atau kapasitansi. Deteksi teradap perubahan kapasitansi lebih mudah dilakukan karena tidak memerlukan elektroda referensi. Akan tetapi, teknik ini memiliki beberapa kekurangan anatara lain kurang sensitif, dan ikatannya idak spesifik,
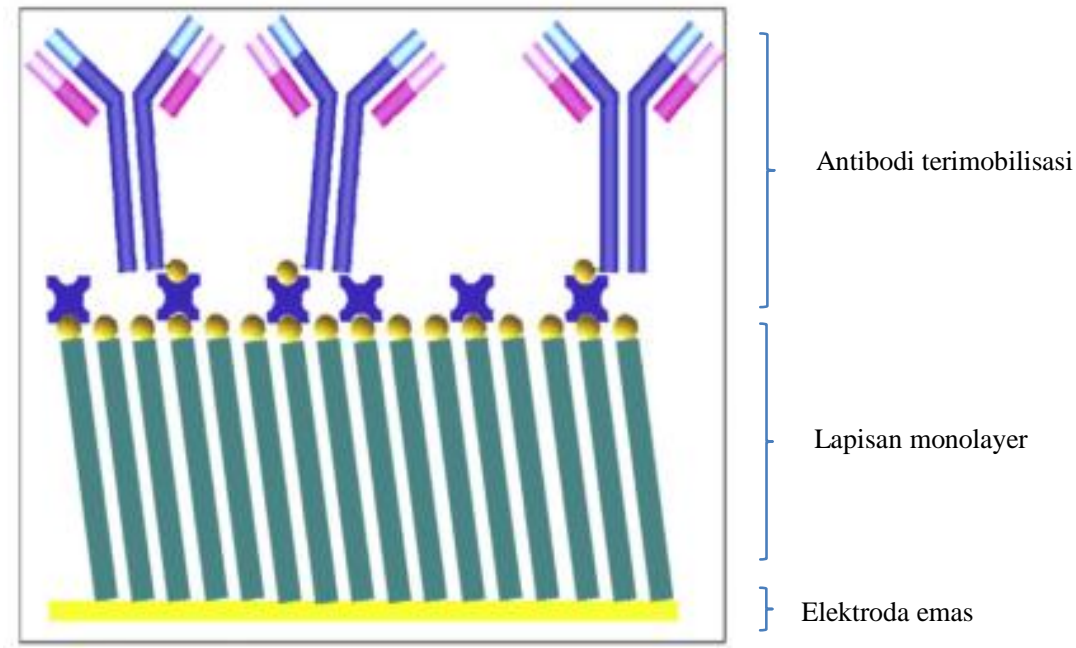

Gambar 2. Biosensor virus yang dikembangkan dengan mengimobilisasi antibodi pada lapisan monolayer di permukaan elektroda emas ${ }^{3}$ 
seingga dapat memberikan hasil positif palsu ${ }^{3}$.

Beberapa biosensor impedansi yang telah dikembangkan anatara lain biosensor untuk deteksi virus influenza, herpes, HBV, $\mathrm{HCV}$, demam, rabies dan $\mathrm{HIV}^{3}$. Salah satu biosensor impedansi untuk deteksi virus berhasil dikembangkan pada tahun 2015. Biosensor ini dikembangkan dengan lapisan multilayer untuk modifikasi elektroda emas. Lapisan multilayer yang digunakan adalah 1,6-heksanaditiol, asam 11merkaptoundekanoat, dan 5 jenis antibodi monoklonal yang diimobilisasi pada permukaan elektroda secara kovalen. Biosensor ini mampu mendeteksi 5 tipe adenovirus. Biosensor ini memiliki kemampuan deteksi yang baik, dengan limit deteksi 30 partikel virus $/ \mathrm{mL}^{21}$. Biosensor impedansi virus yang lain dikembangkan dengan memasangkan metode biosensor ini dengan spektroskopi elektrokimia impedansi (EIS) dan mikroskop gaya atom (AFM) ${ }^{3}$.

Meskipun biosensor impedansi virus ini sangat potensial untuk dikembangkan, namun pengembangan metode ini masih terbilang baru. Pengembangan secara kontinyu sangat diperlukan untuk meningkatkan stabilitas, selektivitas dan sensitivitas elektroda, serta kecepatan respons sehingga mampu digunakan untuk real-time monitoring ${ }^{3}$.

\section{SIMPULAN DAN SARAN}

\section{Simpulan}

Berdasarkan uraian diatas dapat disimpulkan bahwa pengembangan biosensor di bidang pemeriksaan klinik, utamanya untuk deteksi virus patogen memberikan banyak keuntungan. Deteksi virus menggunakan biosensor mampu memeberikan hasil yang lebih cepat, sehingga memungkinkan diagnosis yang lebih cepat serta penanganan yang lebih tepat. Disamping itu, deteksi dini terhadap penyakit patogen dapat mengurangi penyebaran virus serta resiko yang mungkin timbul akibat penyebaran virus tersebut.

Sebagian besar biosensor virus dikembangkan dengan mengimobilisasi asam nukleat atau antibodi pada permukaan elektroda. Interaksi antara antara antibodi dengan DNA virus akan menghasilkan respon yang dapat terkuantifikasi. Biosensor virus yang paling banyak dikembangkan adalah biosensor elektrokimia dengan transduser amperometri, volumetri dan impedansi. Beberapa virus patogen yang telah berhasil dideteksi dengan biosensor elektrokimia antara lain adalah virus HIV, HCV, HBV dan influenza.

\section{Saran}

Perlu disampaikan review pengembangan biosensor virus dengan metode yang lain, seperti sensor optik virus dan sensor pizoelektrik virus, serta 
biosensor untuk deteksi penyakit patogen yang disebabkan oleh bakteri. Selain itu, perlu juga disampaikan pengembangan sensor untuk pemeriksaan di bidang yang lain seperti lingkungan dan industri makanan sehingga dapat memberikan informasi dan wawasan yang baru kepada pembaca dan peneliti. Pelaksanaan kontrol kualitas terhadap hasil yang diberikan oleh biosensor dan sensor juga perlu terus dikembangkan agar hasil yang diberikan selalu akurat, sehingga dapat dijadikan sebagai alternatif metode untuk pemeriksaan di lapangan.

\section{DAFTAR PUSTAKA}

1. E.B. Bahadir and M.K. Sezgintürk, Applications of Commercial Biosensors in Clinical, Food, Environmental, and Biothreat/Biowarfare Analyses, Anal. Biochem., 2015 (478), 107-120.

2. V. Perumal and U. Hashim, Advances In Biosensors: Principle, Architecture And Applications, J. of App. Biomed. 2014 (12), 1-15.

3. Caygill, R.L., Blair, G.E. and Miller, P.A., A Review on Viral Biosensor to Detect Human Pathogens, Anal. Chim. Acta, 2010 (681), 8-15.

4. Yadav, R., Dwivedi, S., Kumar, S. and Chaudhury, Trends and Perspectives of Biosensors for Food and Environmental Virology, Food Environ. Virol, 2010 (2), 53-63.

5. Altintas, Z., Gittens, M., Pocock, J. and Tothill, I.E., Biosensor for Waterborne Viruses: Detection and Removal, Biochimie, 2015 (115), 144-154.

6. Yang, L. and Bashir, R., Electrical/electrochemical impedance for rapid detection of foodborne pathogenic bacteria, Biotechnol. Adv., 2008 (26), 135-150.

7. Ricci, F., Volpe, G., Micheli, L. and Palleschi, G., Anal. Chim. Acta, 2007 (605).

8. Munoz-Berbel, X., Godino, N., Laczka, O., Baldrich, E., Munoz, F.X. and DelCampo, F.J., Impedance-Based Bioensors for Pathogen Detection, Springer, 2008.

9. Wark, A.W., Lee, J., Kim, S., Faisal, S.N. and Lee, H.J., Bioaffinity Detection of Pathogen on Srfaces, J. Ind. Eng. Chem., 2010 (16), 169-177.

10. Malhotra, B. D., Chaubey, A. and Singh, S.P., Prosepect of Cnducting Polymers in Biosensors, Anal. Chim. Acta, 2006 (578), 59-74.

11. Singh, R., Mukherjee, M.D., Sumana, G., Gupta, R.K., Sood, A. and Malhotra, B.D., Biosensors for Pathogen Detection: A Smart Approach Towards Clinical Diagnosis, Sens. And Act. B: Chem., 2014 (197), 385-404.

12. Drummond, T.G., Hill, M.G. and Barton, J.K, Electrochemical DNA Sensors, Nat. Biotechnol., 2003 (21), 1192-1199.

13. Mothershed, E.A. and Whitney, A.M., Nucleic Acid-Based Methods for the Detection of Bacterial Pathogens: Present and Future Considerations for the Clinical Laboratory, Clin. Cim. Acta, 2006 (363), 206-220.

14. Girousi, S., Karastogianni, S. and Serpi, C., Innovative Configurations of Electrochemical DNA Biosensors (A Review), Sens. Electroanal., 2011 (6), 65-87.

15. Yu, D., Blankert, B., Viré, J-C. and Kauffmann, J-M., Biosensors in Drug Discovery Analysis, Anal. Letters., 2005 (38), 1687-1701.

16. Ding, C., Zhao, F., Zhang, M. and Zhang, S., Hybridization Biosensor Using 2,9-Dimethyl-1,10-Phenantroline Cobalt as Electrochemical Indicator for 
Detection of Hepatitis B Virus DNA, Bioelectrochemistry, 2008 (72), 28-33.

17. Arikyosal, D.O., Karadeniz, H., Erdem, A., Sengonul, A., Sayiner, A.A. and Ozsoz, M., Label-Free Electrochemical Hybridization Genosensor for the Detection of Hepatitis B Virus Genotype on the Development of Lamivudine Resistance, Anal. Chem., 2005 (77), 4908-4917.

18. Li, X-M., Ju, H-Q., Du, L-P. and Zhang, S-S., A Nucleic Acid Biosensor for the Detection of a Short Sequence Related to the Hepatitis B Virus Using Bis(Benzimidazole)-Cadmium(II) Dinitrate as an Electrochemical Indicator, $J$. of Inorganic Chem., 2007 (101), 11651171.

19. Zhang, S., Tan, Q., Li, F. and Zhang, X., Hybridization Biosensor Using Diaquabis[N-(2-

Pyridinylmethyl)Benzamide- $\left.\mathrm{K}^{2} \mathrm{~N}, O\right]-$ Cadmium(II) Dinitrate as a New Electroactive Indicator for Detection of Human Hepatitis B Virus DNA, Sens. And Act. B: Chem., 2007 (124), 290296.

20. Ionescu, R.E., Cosnier, S., Herzog, G., Gorgy, K., Leshem, B., Herrmann, S. and Marks, R.S., Enzyme Microb. Technol., 40 (2007), 403.

21. Lin, D., Tang, T., Jed Harrison, D., Lee W.E. and Jemere, A.B., A Regenerating Ultrasensitive Electrochemical Impedance Immunosensor for the Detection of Adenovirus, Biosens. Bioelectron., 2015 (68), 129-134.

22. Riccardi, C.S., Kowalik, J., Josowics, M., Hideko, Y., Mizaikoff, B. and Kranz, C., Label-Free DNA Detection of Hepatitis C Virus (HCV), 210th ECS Meeting, 2006, 585.

23. Liu, S., Hu, Y., Jin, J., Zhang H. and Cai, C., Electrochemical Detection of Hepatitis C Virus based on Site-Specific DNA Cleavage of BamHI Endonuclease, Chem. Commun., 2009 (13).

24. Wang, R., Xue, C., Gao, M., Qi, H. and Zhang, C., Ultratrace Voltammetric
Method for the Detection of DNA Sequence Related to Human Immunodeficiency Virus Type 1, Microchim. Acta, 2011 (172), 291-297.

25. Tran, L.D., Nguyen, B.H., Van Hieu, N., Tran, H.V., Nguyen H. Le. and Nguyen, P.X., Electrochemical Detection of Short HIV Sequences on Chitosan/Fe $3 \mathrm{O} 4$ Nanoparticle Based Screen Printed Electrodes, Mater. Sci. Eng. C, 2011 (31), 477-485.

26. Chen, X., Xie, H., Seow, Z.Y. and Gao, Z., Biosensors and Bioelectronics an Ultrasensitive DNA Biosensor based on Enzyme-Catalyzed Deposition of Cupric Hexacyanoferrate Nanoparticles, Bioens. And Bioelectron., 2010 (25), 1420-6.

27. Zari, N., Amine, A. and Enhaji, M.M., Label-Free DNA Biosensor for Electrochemical Detection of Short DNA Sequences Related to Human Papilloma Virus, Anal. Letters, 2009 (42), 519-535. 
